\title{
Application of intragenic DNA probes in prenatal screening for retinoblastoma gene carriers in the United Kingdom
}

\author{
Z O Onadim, C D Mitchell, P C Rutland, B G Buckle, M Jay, J L Hungerford, \\ K Harper, J K Cowell
}

\begin{abstract}
Restriction fragment length polymorphisms (RFLPs) in 55 families affecte 1 by retinoblastoma have been studied using recombinant DNA probes derived from within the retinoblastoma predisposition gene. Only six families were uninformative for any of the DNA polymorphisms. The remaining 49 families can be offered prenatal screening. No obligate recombinations between any of the polymorphic loci and the retinoblastoma phenotype were observed. Four previously unknown cases of non-penetrance were identified. Prenatal testing for the inheritance of mutant alleles was performed in two cases and perinatal screening in two additional cases. One fetus inherited the normal allele from the affected parent and is therefore not at risk of retinoblastoma; the second fetus inherited the mutant allele and will require frequent screening for early detection of retinoblastoma. Both perinatal tests showed the absence of the mutant allele.
\end{abstract}

Retinoblastoma, although rare, is the most common ophthalmic malignancy in childhood. It has been the focus of a large amount of research, because in about one third of cases the predisposition to cancer is dominantly inherited from affected parents. ${ }^{12}$ Early detection of retinoblastoma ensures a better prognosis, both for life and for vision. Until recently the only available method of early detection was regular full ophthalmological assessment under anaesthetic. In practice this means that all children at risk of retinoblastoma on clinical grounds are screened. As the retinoblastoma mutation is not fully penetrant (not all subjects carrying the dominant mutant gene show the mutant phenotype) and the disease is able to 'skip' a generation, even children of unaffected subjects from within an affected family must be considered 'at risk' as well as those of apparently sporadic cases. Thus there is considerable investment in a small number of patients of whom less than half ultimately develop tumours. In addition, many patients with retinoblastoma have elected not to have children because of the risk of an offspring being similarly affected. The ability to detect the inheritance of normal or mutant retinoblastoma alleles (one of a series of possible alternative forms of a given gene differing in DNA sequence) would allow clinical screening procedures to focus on those patients at high risk of developing retinoblastoma, and make pregnancy, with prenatal testing and termination of predisposed fetuses, an option for those families not wanting to have an affected child.

The discovery that the esterase- $\mathrm{D}$ gene lay in chromosome band $13 \mathrm{q} 14^{3}$ meant that a protein polymorphism (the existence of two or more genetically different classes in the same interbreeding population) for that enzyme could be used for 'gene tracking' in families with retinoblastoma. ${ }^{4}$ Although close linkage was firmly established, ${ }^{5-8}$ the low incidence of heterozygotes in the population made it impractical to apply this technique widely. Randomly isolated DNA sequences, which had been mapped around the $13 q 14$ region, and which recognised restriction fragment length polymorphisms (RFLPs_variations occurring within a species in the length of DNA fragments generated by a specific endonuclease) were used for prenatal screening. ${ }^{910}$ Succes was, however, limited because of recombination (the occurrence of progeny with combinations of genes other than those that occurred in the parents as a result of independent assortment or crossing over) between these markers and the retinoblastoma locus. ${ }^{11}$ In 1986 Friend $e t$ al isolated a candidate retinoblastoma gene that showed frequent structural abnormalities in retinoblastoma tumour cells. ${ }^{12}$ Mutations of this gene have now been found in somatic cells of predisposed subjects. ${ }^{13-14}$ It is not possible to recognise RFLPs directly using this complementary DNA (cDNA), but recently Wiggs et al isolated a series of DNA probes from within the genomic sequence that recognise high frequency RFLPs. ${ }^{16}$ We have investigated the segregation of alleles detected by these sequences in a large series of families with retinoblastoma and report on their application to family linkage studies.

\section{Subjects and methods}

Most families were identified in the ophthalmic oncology clinics at St Bartholomew's Hospital and Moorfields Eye Hospital, although some were submitted from other regional centres. In each case the diagnoses of affected individuals has been confirmed by an experienced ophthalmologist (JLH). Blood samples were collected from as many relevant family members as possible and stored at $-80^{\circ} \mathrm{C}$ until required. For many of the key family members lymphoblastoid cell lines were also generated. Prenatal samples were obtained either by chorionic villus sampling or by amniocentesis.

DNA was prepared from white blood cells, lymphoblastoid cell lines, chorionic villi, or cultured fetal fibroblasts using standard methods. ${ }^{17}$ Between 2-5 $\mu \mathrm{g}$ DNA from each 
member of the family was digested with the appropriate restriction endonuclease, size fractionated by electrophoresis through $1 \%$ agarose gels, and transferred to nylon membranes (Hybond-N) as described by Southern. ${ }^{18}$ All DNA probes were labelled to high specific activity by the oligoprimer extension method. ${ }^{19}$ Prehybridisation and hybridisation were carried out in quadruple strength $0 \cdot 15 \mathrm{M}$ sodium chloride and $0.015 \mathrm{M}$ sodium citrate (SSC) sonicated boiled salmon sperm, $10 \mu \mathrm{g} / \mathrm{ml}$ polyadenylic acid and $0.1 \%$ sodium dodecyl sulphate (SDS) at $65^{\circ} \mathrm{C}$ for 16 hours. Filters were then washed at $65^{\circ} \mathrm{C}$ for two washes of 15 minutes each in double strength SSC/0.1\% SDS, and then exposed to Kodak XAR-5 autoradiographic film with intensifying screens for 16-72 hours.

Family pedigree data were prepared for analysis using the progam LINKSYS, ${ }^{20}$ and log of the odds scores were calculated using the program LIPED 6. ${ }^{21}$ Assuming that the frequency of new gene mutations gamete is $1.5 \times 10^{-5}$, data were analysed for a penetrance (the proportion of subjects in a specified group that show the expected phenotype under a set of environmental conditions) of 0.9 .

\section{Results}

PATTERN OF INHERITANCE

In our series there were 17 families in which subjects had either an affected parent or sibling, and also an affected child. Three of these 29 subjects were not themselves affected and ophthalmological examination of their retinas failed to detect evidence of regressed tumours. From these observations we assess the penetrance of the retinoblastoma gene as $90 \%$ and we have used these figures to calculate the log of the odds scores.

The inheritance of the retinoblastoma phenotype follows the normal pattern of autosomal dominant inheritance in most families (fig 1). Family RBF-12 is unusual in that each of the affected members has only a unifocal tumour or evidence of spontaneous regression (fig 2). Phenotypic analysis indicates that there is an apparently unaffected transmitting member (II.7). Unfortunately this subject was not available for ophthalmological examination; it is possible he also had regressed tumours, especially as evidence of incomplete penetrance in another member of the family was detected using molecular probes (fig 2). The log of the odds score for this family was -0.03 at $\theta=0$ and $90 \%$ penetrance and 0.178 at $\theta=0$ and a penetrance of $80 \%$. $\theta$ Represents the proportion of recombinants out of all the opportunities for recombination. Assessing the log of the odds score, assuming $90 \%$ penetrance, the maximum value of 0.96 was obtained at $\theta=0.2$ (table 1 ). In family RBF-04 three affected siblings were
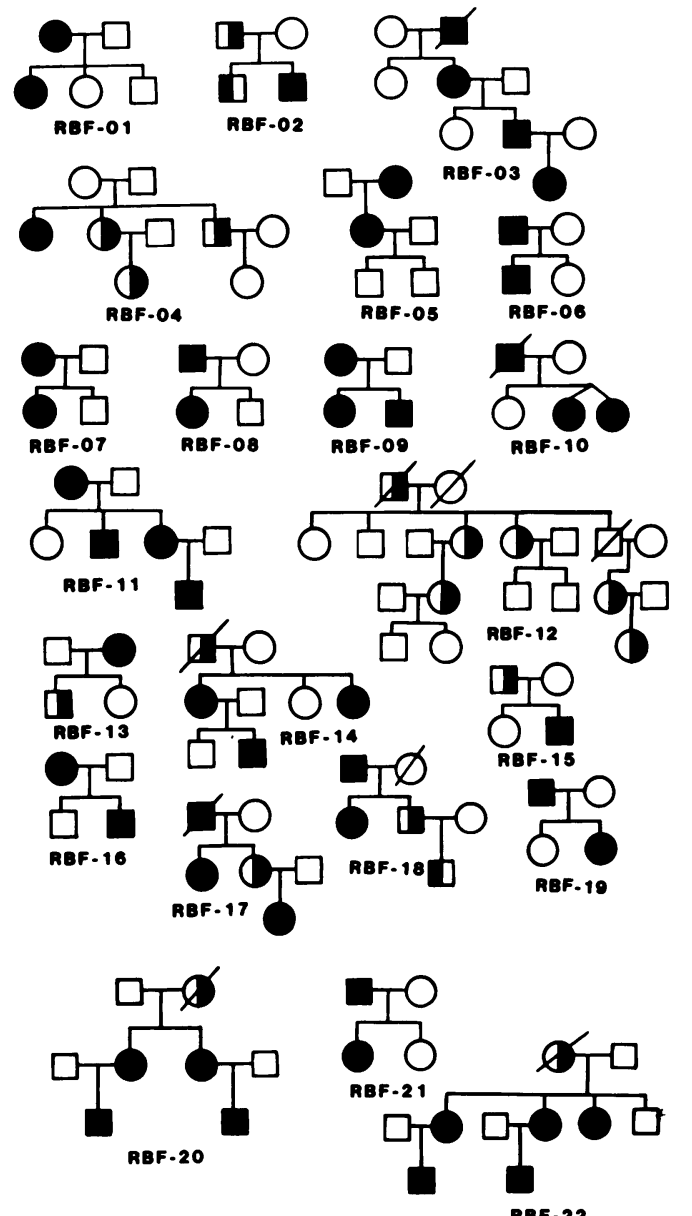

RBF-22

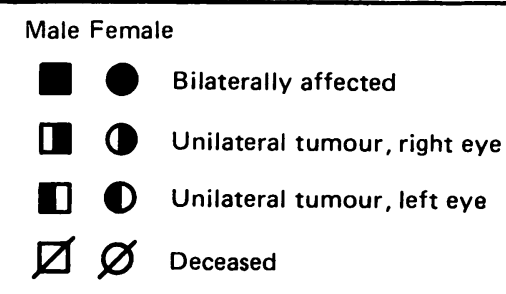

Figure 1 Structure of family pedigrees used in linkage analysis with the intragenic, polymorphic DNA gene probes.

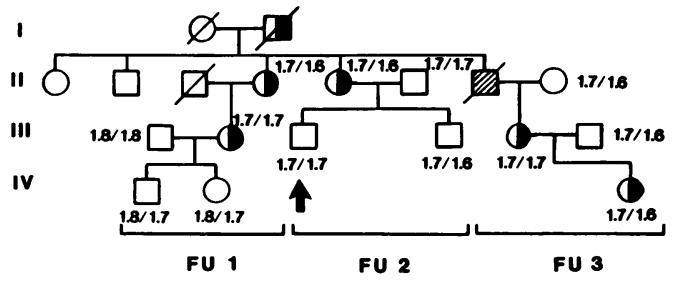

Figure 2 Segregation of RS2.0 alleles in family $R B F-12$. The $R b$ phenotype is segregating with the $1 \cdot 7$ allele. In family unit $(F U) 1$ the affected subject $(I I I .2)$ is homozygous so it is not possible to determine whether their children are carriers (IV.1,IV .2). In family unit 2 both children are unaffected but III.3 (arrow) has received the $1 \cdot 7 \mathrm{~Kb}$ allele from his father and therefore must be a gene carrier. In family unit 3 both affected members have only retinal scarring as the
sign of the retinoblastoma gene and the grandfather (II.7) was unavailable for analysis.

Table 1 Log of the odds scores at different values of $\theta$ for the two families that showed evidence of incomplete penetrance

\begin{tabular}{|c|c|c|c|c|c|c|c|c|c|c|c|}
\hline \multirow[t]{2}{*}{ Families } & \multicolumn{11}{|l|}{ Score } \\
\hline & $\overline{0.0}$ & 0.001 & 0.005 & $0 \cdot 1$ & 0.15 & 0.2 & 0.25 & 0.3 & 0.35 & 0.4 & 0.45 \\
\hline $\begin{array}{l}\text { RBF-04 } \\
\text { RBF-12 }\end{array}$ & $\begin{array}{r}0.048 \\
-0.030\end{array}$ & $\begin{array}{r}0.048 \\
-0.028\end{array}$ & $\begin{array}{l}0.056 \\
0.037\end{array}$ & $\begin{array}{l}0.058 \\
0.072\end{array}$ & $\begin{array}{l}0.055 \\
0.090\end{array}$ & $\begin{array}{l}0.048 \\
0.096\end{array}$ & $\begin{array}{l}0.039 \\
0.092\end{array}$ & $\begin{array}{l}0.029 \\
0.079\end{array}$ & $\begin{array}{l}0.019 \\
0.058\end{array}$ & $\begin{array}{l}0.009 \\
0.033\end{array}$ & $\begin{array}{l}0.003 \\
0.010\end{array}$ \\
\hline Total & 0.018 & 0.02 & 0.093 & $0 \cdot 130$ & 0.145 & 0.144 & 0.131 & $0 \cdot 108$ & 0.068 & 0.042 & 0.013 \\
\hline
\end{tabular}


born to unaffected parents. In this family it was not possible to determine whether one of the parents was a true case of incomplete penetrance or whether one or the other was a gonadal mosaic for the mutation. The maximum log of the odds score in this family assuming a penetrance of $90 \%$ was 0.058 at $\theta=0 \cdot 1$. The $\log$ of the odds scores for 20 informative families were calculated and are shown in table 2 . The cumulative scores, including that derived from family RBF-12, was $5 \cdot 947$ at $\theta=0$ and $90 \%$ penetrance.

GENE TRACKING WITH INTRAGENIC PROBES

Five unique DNA sequence probes from within the genomic sequence of the $4 \cdot 7 R(R B 1)$ gene were used in this study (table 3 ). ${ }^{16}$ Each probe recognises RFLPs that occur sufficiently frequently to be of value in linkage analysis.

Fifty five families were analysed, and they form two groups. The first $(n=22)$ contained at least two children and had affected family members in at least two generations, in most cases allowing log of the odds scores to be calculated. The pedigrees of these families are shown in fig 1. In the second group of families $(n=33)$, either there was only one affected child, or not all family members were available for testing,

Table 2 Log of the odds scores from informative Table 2 Log of the odd
retinoblastoma families

\begin{tabular}{lc}
\hline Families & Penetrance $90 \%$ \\
\hline RBF-02 & $0 \cdot 301$ \\
RBF-03 & $0 \cdot 260$ \\
RBF-04 & $0 \cdot 048$ \\
RBF-05 & $0 \cdot 223$ \\
RBF-06 & $0 \cdot 260$ \\
RBF-07 & $0 \cdot 260$ \\
RBF-08 & $0 \cdot 260$ \\
RBF-09 & $0 \cdot 301$ \\
RBF-10 & $0 \cdot 561$ \\
RBF-11 & $0 \cdot 862$ \\
RBF-12 & $0 \cdot 030$ \\
RBF-13 & $0 \cdot 260$ \\
RBF-14 & $0 \cdot 422$ \\
RBF-15 & $0 \cdot 260$ \\
RBF-16 & $0 \cdot 260$ \\
RBF-17 & $0 \cdot 125$ \\
RBF-18 & $0 \cdot 085$ \\
RBF-19 & $0 \cdot 260$ \\
RBF-20 & $0 \cdot 204$ \\
RBF-21 & $0 \cdot 561$ \\
RBF-22 & $0 \cdot 204$ \\
\hline Total & 5.947 \\
\hline
\end{tabular}

but we were able to establish the allele with which the retinoblastoma phenotype was segregating in order to offer prenatal screening in the future. All the families were selected because prenatal screening could be offered to at least one family member if requested.

Allele frequencies for the five probes in the British population were determined from an analysis of unrelated subjects within the families studied, and are listed in table 3 . The most highly informative probe was $\mathrm{RS} 2 \cdot 0$ which, following digestion of the genomic DNA with the RSA1 restriction enzyme, identified a variable number tandem repeat (VNTR-an aberration in which two identical chromosomal segments lie one behind the other. The order of the repeat unit in each segment is the same). The polymorphism identified by $\mathrm{RS} 2 \cdot 0$ detected a VNTR of roughly 50 base pairs, with eight alleles so far detected. ${ }^{16}$ To separate these alleles, DNA $(2-3 \mu \mathrm{g})$ is run overnight in an 0.4 $\mathrm{cm}$ thick, $1 \cdot 2 \%$ agarose gel until lambda markers below $1.0 \mathrm{~Kb}$ in size have migrated off the bottom of a $20 \mathrm{~cm}$ gel. Under these conditions it is usually possible to distinguish betweeen alleles differing in size by only 50 base pairs. Variations in gel thickness, however, conditions which result in non-homogeneity of the gel, or local heat gradients during electrophoresis can distort the migration rate of the DNA restriction fragments. Thus it is difficult to establish the sizes of alleles and compare them among gels. This almost certainly accounts for the discrepancy between our estimate of allele frequencies and those reported by Wiggs et al. ${ }^{16}$ Within a single gel, however, the mendelian inheritance can easily be followed (fig 3). In some families only key members were analysed with this probe. If they were heterozygotes the analysis was extended to the remaining family members. Homozygotes were not investigated further but were analysed with the other probes, which identify less frequent RFLPs (table 4). The second most informative probe was PRO.6 and the third was M1.8 (fig 4), the two other less informative probes being used only if required.

Six families $(11 \%)$ were uninformative for all the probes used so far and cannot therefore be offered prenatal screening. Of the remainder,

Table 3 Summary of frequencies with which alleles occurred in the population of the United Kingdom intragenic retinoblastoma probes

\begin{tabular}{|c|c|c|c|c|c|c|}
\hline Probe & Enzyme & $\begin{array}{l}\text { No of } \\
\text { individuals }\end{array}$ & $\begin{array}{l}\text { Size of } \\
\text { allele } \\
(k b)\end{array}$ & $\begin{array}{l}\text { Percentage } \\
\text { frequency } \\
\text { of allele in } \\
\text { population }\end{array}$ & No of families & $\begin{array}{l}\text { No (\%) } \\
\text { that were } \\
\text { informative }\end{array}$ \\
\hline $\mathrm{RS} 2 \cdot 0$ & RSA1 & 107 & $\begin{array}{l}2.0 \\
1.95 \\
1.9 \\
1.85 \\
1.8 \\
1.75 \\
1.7 \\
1.6 \\
1.5\end{array}$ & $\begin{array}{l}0.09 \\
0.10 \\
0.23 \\
0.13 \\
0.28 \\
0.02 \\
0.06 \\
0.05 \\
0.04\end{array}$ & 55 & $40(73)$ \\
\hline PRO·6 & Xbal & 132 & & $\begin{array}{l}0.48 \\
0.52\end{array}$ & 45 & $19(42)$ \\
\hline$M 1 \cdot 8$ & BamHl & 66 & & $\begin{array}{l}0.34 \\
0.66\end{array}$ & 30 & $13(39)$ \\
\hline RO 6 & Tth1111 & 64 & $\begin{array}{l}4.95 \\
4 \cdot 35\end{array}$ & $\begin{array}{l}0.60 \\
0.40\end{array}$ & 14 & $4(29)$ \\
\hline HSO 5 & Kpn 1 & 43 & $\begin{array}{r}12 \cdot 0 \\
8 \cdot 0\end{array}$ & $\begin{array}{l}0.93 \\
0.07\end{array}$ & 10 & 0 \\
\hline
\end{tabular}


Table 4 Families with retinoblastoma in which a given RFLP was informative in a particular kindred

\begin{tabular}{|c|c|c|c|c|c|}
\hline \multirow[t]{2}{*}{ Family } & \multicolumn{4}{|l|}{ Probes } & \multirow[b]{2}{*}{$p 35 R 0.6$} \\
\hline & $p 68 R S 2 \cdot 0$ & $p 88 R 0 \cdot 6$ & $p 123 M 1 \cdot 8$ & p95HSO.5 & \\
\hline $\begin{array}{l}\text { RBF-01 } \\
\text { RBF-02 } \\
\text { RBF-03 } \\
\text { RBF-04 } \\
\text { RBF-05 } \\
\text { RBF-06 } \\
\text { RBF-07 } \\
\text { RBF-08 } \\
\text { RBF-09 } \\
\text { RBF-10 } \\
\text { RBF-11 } \\
\text { RBF-12 } \\
\text { RBF-13 } \\
\text { RBF-14 } \\
\text { RBF-15 } \\
\text { RBF-16 } \\
\text { RBF-17 } \\
\text { RBF-18 } \\
\text { RBF-19 } \\
\text { RBF-20 } \\
\text { RBF-21 } \\
\text { RBF-22 }\end{array}$ & $\begin{array}{l}\text { Yes } \\
\text { Yes } \\
\text { No } \\
\text { Yes } \\
\text { Yes } \\
\text { Yes } \\
\text { Yes } \\
\text { Yes } \\
\text { Yes } \\
\text { Yes } \\
\text { No } \\
\text { Yes } \\
\text { Yes } \\
\text { Yes } \\
\text { Yes } \\
\text { Yes } \\
\text { Yes } \\
\text { Yes } \\
\text { No } \\
\text { Yes } \\
\text { Yes } \\
\text { Yes }\end{array}$ & $\begin{array}{l}\text { No } \\
\text { No } \\
\text { Yes } \\
\text { No } \\
\text { Yes } \\
\text { No } \\
\text { Not tested } \\
\text { Yes } \\
\text { No } \\
\text { Not tested } \\
\text { No } \\
\text { Yes } \\
\text { Yes } \\
\text { No } \\
\text { No } \\
\text { No } \\
\text { No } \\
\text { Yes } \\
\text { No } \\
\text { Yes } \\
\text { No } \\
\text { No }\end{array}$ & $\begin{array}{l}\text { No } \\
\text { No } \\
\text { No } \\
\text { No } \\
\text { Not tested } \\
\text { Yes } \\
\text { No } \\
\text { Yes } \\
\text { Yes } \\
\text { Not tested } \\
\text { No } \\
\text { Yes } \\
\text { Yes } \\
\text { No } \\
\text { Yes } \\
\text { Yes } \\
\text { No } \\
\text { Yes } \\
\text { No } \\
\text { Not tested } \\
\text { Yes } \\
\text { No }\end{array}$ & $\begin{array}{l}\text { Yes } \\
\text { Yes } \\
\text { No } \\
\text { No } \\
\text { Not tested } \\
\text { Yes } \\
\text { Not tested } \\
\text { Yes } \\
\text { No } \\
\text { Not tested } \\
\text { No } \\
\text { No } \\
\text { No } \\
\text { No } \\
\text { Yes } \\
\text { No } \\
\text { No } \\
\text { No } \\
\text { No } \\
\text { Not tested } \\
\text { Not tested } \\
\text { Not tested }\end{array}$ & $\begin{array}{l}\text { Not tested } \\
\text { No } \\
\text { No } \\
\text { No } \\
\text { Not tested } \\
\text { No } \\
\text { Not tested } \\
\text { No } \\
\text { Not tested } \\
\text { Not tested } \\
\text { Not tested } \\
\text { Not tested } \\
\text { Not tested } \\
\text { No } \\
\text { Not tested } \\
\text { Not tested } \\
\text { No } \\
\text { Not tested } \\
\text { Yes } \\
\text { Not tested } \\
\text { Yes } \\
\text { No }\end{array}$ \\
\hline
\end{tabular}

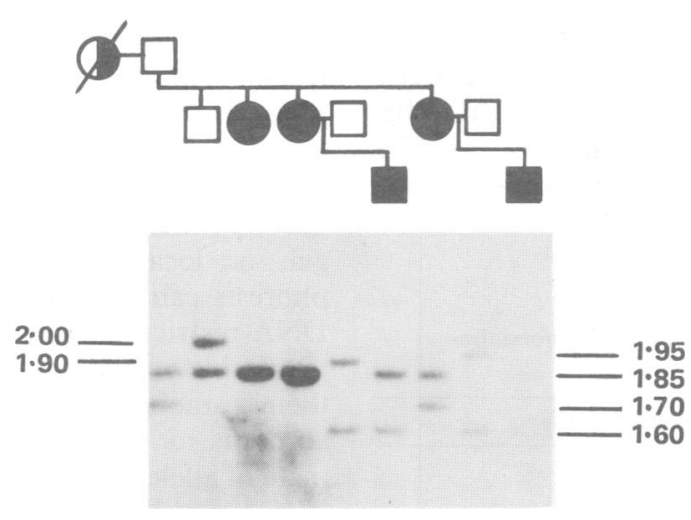

Figure 3 Linkage analysis in family $R B F-22$ using the $R S 2 \cdot 0$ intragenic $R b$ probe. DNA from family members shown in the pedigree (fig 1) was digested with RSAI and six different alleles ranging in size between $2 \cdot 0-1 \cdot 6 \mathrm{~K} b$ were detected. In this family the mutant gene is segregating with the $1 \cdot 85 \mathrm{~Kb}$ allele. The genotype of the subject represented in lane 9 , showing only weak hybridisation, was $1 \cdot 85 / 1 \cdot 60$.

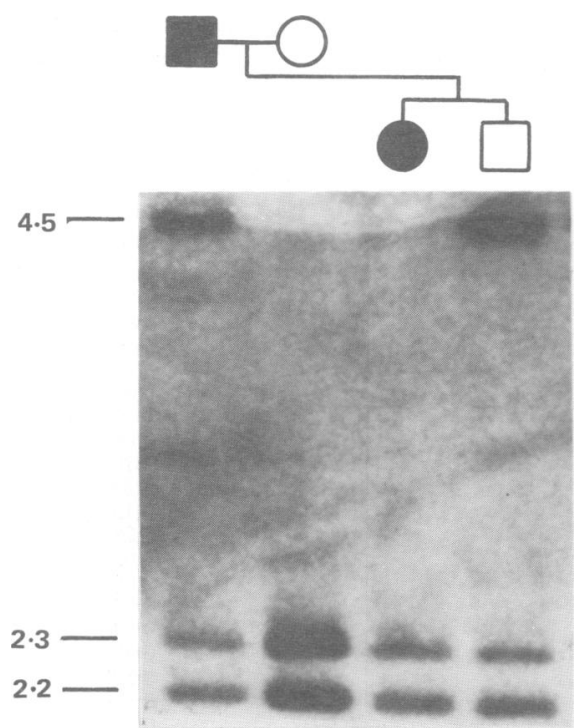

Figure 4 Linkage analysis in family $R B F-8$ using the $M 1 \cdot 8$ intragenic $R b$ probe. Individual alleles are either $4 \cdot 5 \mathrm{~Kb}$ long or a doublet, $2 \cdot 3$ and $2 \cdot 2 \mathrm{~Kb}$ long. In this case the disease phenotype is segregating with the lower allele.
$73 \%$ were informative with $\mathrm{RS} 2 \cdot 0$ alone. Of the 16 families not informative for RS2 $\cdot 0,11(69 \%)$ were informative for PRO.6.

In several cases, though the transmitting subject was heterozygous, the children became homozygous for a particular probe. In these cases the analysis was extended so that informative probes were also available for affected subjects in the second generation.

\section{PRENATAL SCREENING}

The possibility of screening for carriers has been discussed with each family. So far two infants have been screened perinatally and in both cases it was possible to say that they were not carriers. Two families have taken advantage of prenatal screening. In the first (RBF-14), DNA was obtained by chorionic villus sampling, ${ }^{22}$ and in the second (RBF-01) from cultured amniotic fluid cells obtained for chromosome analysis because of advanced maternal age. The analysis of family RBF-01 with the RS2.0 probe is shown in fig 5 . The affected and unaffected children have both inherited the same maternal allele, suggesting that the unaffected daughter apparently carries the mutant allele, as does the fetus. Alternatively, a recombination event within the $\mathrm{RB} 1$ locus in the affected daughter, proximal to the RS2.0 site, may have occurred. Because available flanking markers were homozygous in the transmitting parent, however, it is not possible to exclude recombination. This family was not included in the log of the odds score calcula-

$185 / 1.6$

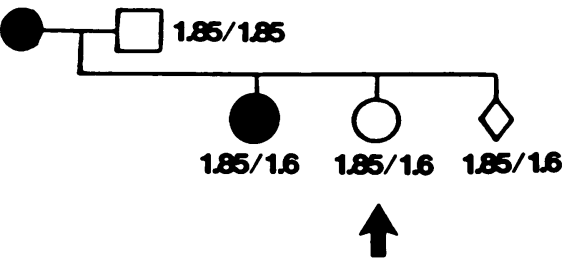

Figure 5 Segregation of $R S 2 \cdot 0$ alleles in family $R B F-01$. The retinoblastoma phenotype is segregating with the $1.6 \mathrm{~Kb}$ allele, which is also present in the unaffected 8 year old daughter (arrow) as well as in the amniotic cell from the fetus $(\diamond)$. 
tions. No obligate recombination was detected among markers or among the markers and the retinoblastoma phenotype in any of the other families. The region of the genome covered by the retinoblastoma gene is approximately 200 kb. This distance represents about 0.2 centimorgan (cM) and therefore recombination frequency should be low.

\section{Discussion}

Using five intragenic, unique sequence DNA probes for the retinoblastoma locus, $90 \%$ of families were informative for prenatal screening. As we have used probes from within the retinoblastoma gene itself, recombination among markers is unlikely. Nevertheless in the absence of mutation specific probes, recombination between marker and mutation cannot be excluded. Data from this series and from that of Wiggs et al ${ }^{16}$ give a cumulative log of the odds score of 14.55 at $\theta=0$, assuming a penetrance of 0.9 .

Not all subjects who inherit a mutant retinoblastoma gene develop the tumour, a phenomenon referred to as incomplete penetrance. In the inherited form of retinoblastoma it is believed that non-penetrance arises because the predisposed retinoblasts do not suffer the second mutation that would result in the development of malignancy. Vogel reviewed all published pedigrees up to 1979 and calculated that penetrance was between 0.996 to 0.927 , with a higher frequency in offspring of bilaterally affected parents. ${ }^{1}$ Our calculation of penetrance (clinically defined) is in agreement with these figures, though selection bias is possible as the families in this series were mostly from a single referral hospital. Using RFLP analysis we have identified apparently unaffected gene carriers. Presumably these subjects remain at risk of other tumours associated with retinoblastoma, and their offspring are at risk of retinoblastoma; they will now receive appropriate genetic counselling. Conversely, the (unaffected) subjects shown not to be carriers of the predisposition allele may be reassured that they do not carry the mutant allele.

Incomplete penetrance can also be the result of inheritance of a balanced translocation where the unbalanced form gives rise to tumour predisposition $^{23}$ or missed diagnosis where apparently unaffected gene carriers show evidence of regressed tumours or retinomas. ${ }^{24}$ Excluding family RBF-01, where the issue of penetrance has still to be resolved, two other families showed evidence of unaffected gene carriers. In one family, for whom gene tracking using the intragenic probes was not possible, the incomplete penetrance was completely predictable from phenotype analysis, the remainder of the affected subjects having the full range of phenotypic expression of the retinoblastoma gene. In family RBF-12, however, no subject has had bilateral tumours, and in one family nucleus affected members bore only retinal scarring. This family is reminiscent of that reported by Connolly et al. ${ }^{25}$ It is possible that in this family the phenotype may result from specific mutations resulting in non-penetrance, rather than contributing to that part of the
Poisson distribution described by Knudson, where the second mutation has not occurred. ${ }^{26}$ The availability of the retinoblastoma gene sequence may answer this question in the future. Within this family we have detected unaffected gene carriers who do not have retinal scarring. Cytogenetic analysis (JK Cowell, unpublished observations) failed to show any serious structural abnormality of chromosome 13 in affected family members, and their esterase-D gene concentrations were normal, ${ }^{27}$ precluding any large deletion in 13q14.

There are ethical issues to consider in the prenatal diagnosis of a disease such as retinoblastoma, which is rarely lethal and has no effect on mental ability. Although the vision of some patients who are treated early for single tumours may not be greatly affected, in some cases enucleation (which may be bilateral) is necessary. This operation is disfiguring, and many parents have expressed an interest in screening. Even though the child will survive the primary tumour, 5-15\% will develop second tumours in adolescence, usually soft tissue sarcomas or osteosarcomas. ${ }^{28} 29$ In family RBF-14, the first to opt for prenatal screening, many of the members had bilateral disease, and were blind or partly sighted. It was their belief that in the event of a fetus inheriting a mutant allele, termination of pregnancy was acceptable. In the second family, RBF-01, termination was not acceptable, particularly as an unaffected previous child could have been the result of nonpenetrance or a recombination between the probe and the predisposing mutation. In both cases the validation of the results awaits the passage of time.

In linkage studies such as this it is essential that the affected parent is heterozygous for at least one of the polymorphisms. Such is the variety of probes now available that most families are informative. Using standard linkage analysis prenatal screening can be offered to $90 \%$ of families, but new probes are still required for the remainder. The discovery of a VNTR, based on a four base pair repeat in the region adjacent to exon $20,{ }^{30}$ should be an important addition to the screening armoury. There are between 10 and 24 different alleles in this system and it is estimated that $97 \%$ of subjects will be heterozygous at this locus. Although the techniques used for this analysis are more complex than in conventional agarose gel electrophoresis, specialist genetic laboratories should be able to apply this procedure to prenatal screening. The ultimate goal is to determine whether each newly diagnosed case of retinoblastoma is a carrier; there is likely to be a whole range of mutations in different families. Though the whole retinoblastoma gene is large, the 27 exons occupy only approximately $5 \mathrm{~Kb}$. Polymerase chain reaction amplification, and sequencing of each exon and their flanking regions offers a realistic possibility in the near future of providing unequivocal evidence for specific (gene) mutations in individual families. If this technique can be applied to the analysis of apparently sporadic cases it should be possible to detect carriers in the absence of a family history. 
We thank all the those general practitioners in the UK who collected blood and sent it to us, and Dr T Dryja for making the intragenic retinoblastoma probes available to us. We also thank Dr J Pritchard and Dr M Pembrey for their critical reading of the manuscript. Zerrin Onadim was support

1 Vogel W. The genetics of retinoblastoma. Hum Genet 1979; 52:1-54.

2 Jay M, Cowell JK, Hungerford J. Register of retinoblastoma: preliminary results. Eye 1988;2:102-5.

3 Sparkes RS, Sparkes MC, Wilson MG, et al. Regional assignment of genes for human esterase $D$ and retinoblastoma to chromosome band 13q14. Science 1980;208:1042-4

4 Hopkinson DA, Mestriner MA, Cortner J, Harris $H$. Esterase-D: a new human polymorphism. Ann Hum Genet 1973;37:119-37.

5 Sparkes RS, Murphree AL, Lingua RW, et al. Gene for hereditary retinoblastoma assigned to human chromosome 13 by linkage to esterase-D. Science 1983;219:971-3.

6 Mukai S, Rapaport JM, Shields JA, Augsburger JJ, Dryja TP. Linkage of genes for human esterase-D and hereditary retinoblastoma. Am $\mathcal{F}$ Ophthalmol 1984;97:681-5.

7 Halloran SL, Boughman JA, Dryja TP, et al. Accuracy of the detection of the retinoblastoma gene by esterase-D linkage. detection of the retinoblastoma gene
Arch Ophthalmol 1985;103:1329-31.

8 Cowell JK, Jay M, Rutland P, Hungerford J. An assessment of the usefulness of electrophoretic variants of esterase D in the antenatal diagnosis of retinoblasto

9 Cavenee W, Leech R, Mohandas T, Pearson P, White R. Isolation and regional localisation of DNA segments revealin polymorphic loci for human chromosome 13. Am $\mathcal{~} \mathrm{Hum}$ Genet 1984;36:10-24.

10 Dryja TP, Cavenee W, White R, et al. Homozygosity of chromosome 13 in retinoblastoma. $N$ Engl 7 Med 1984;310: 550-3.

11 Cavenee WK, Murphree AL, Schull MM, et al. Prediction of familial predisposition to retinoblastoma. $N$ Engl f Med 1986;314:1201-7.

12 Friend SH, Bernards R, Rogelj S, et al. A human DNA segment with properties of the gene that predisposes to ment with properties of the gene that predisposes to
retinoblastoma and osteosarcoma. Nature 1986;323:643-6.

13 Dunn JM, Phillips RA, Becker A, Gallie BL. Identification of germline and somatic mutations affecting the retinoblasof germline and somatic mutations affecting
toma gene. Science 1988;241:1797-800.

14 Mitchell CD, Cowell JK. Predisposition to retinoblastom due to a translocation within the $4 \cdot 7 \mathrm{R}$ locus. Oncogene $1989 ; 4: 253-7$.
15 Higgins MJ, Hansen MF, Cavenee WK, Lalande M. Molecular detection of chromosomal translocations that disrupt the putative retinoblastoma susceptibility locus. Mol Cell Biol 1989;9:1-5.

16 Wiggs J, Nordenskjeld M, Yandell D, et al. Prediction of the risk of hereditary retinoblastoma using DNA polymorphisms within the retinoblastoma gene. N Engl f Med 1988; 318:151-7.

17 Maniatis T, Fritsch EF, Sambrook J, eds. Molecular cloning: a laboratory manual. New York: Cold Spring Harbour Press, 1982 .

18 Southern E. Detection of specific sequences among DNA fragments separated by gel electrophoresis. $7 \mathrm{Mol} \mathrm{Biol}$ fragments separated

19 Feinberg AP, Vogelstein B. A technique for radiolabeling DNA restriction endonuclease fragments to high specific activity. Anal Biochem 1983;132:6-13.

20 Attwood J, Bryants S. A computer program to make linkage analysis with LIPED and LINKAGE easier to perform and less prone to input errors. Ann Hum Genet 1988;52:259-62.

$21 \mathrm{Ott} \mathrm{J}$. Estimation of the recombination fraction in human pedigrees: efficient computation of the likelihood for human linkage studies. Am 7 Hum Genet 1974;26:588-97.

22 Mitchell $\mathrm{CD}$, Nicolaides $\mathrm{K}$, Kingston J, Hungerford J, Jay M, Cowell JK. Prenatal exclusion of hereditary retinoblastoma. Lancet 1988;i:826.

23 Strong LC, Riccardi VM, Ferrel RE, Sparkes RS. Familial retinoblastoma and chromosome 13 deletion transmitted retinoblastoma and chromosome 13 deletion transmitted

24 Gallie BL, Ellsworth RM, Abramson DH, Phillips RA. Retinoblastoma: spontaneous regression of retinoblastoma
or benign manifestation of the mutation? Br f Cancer 1982; or benign $15.513-21$.

25 Connolly MJ, Payne RH, Johnson G, et al. Familial, EsDlinked, retinoblastoma with reduced penetrance and variable expressivity. Hum Genet 1983;65:122-4.

26 Knudson AG. Mutation and cancer: statistical study of retinoblastoma. Proc Natl Acad Sci USA 1971;68:820-3.

27 Cowell JK, Rutland P, Jay M, Hungerford J. Deletions of the esterase-D locus from a survey of 200 retinoblastoma patients. Hum Genet 1986;72:164-7.

28 Abramson DH, Ellsworth RM, Kitchin FD, Tung G. Second nonocular tumours in retinoblastoma survivors. Are they radiation-induced? Ophthalmology 1984;91:1351-5.

29 Sanders BM, Jay M, Draper GT, Roberts EM. Non-ocular cancer in relatives of retinoblastoma patients. Br 7 Cancer cancer in relatives

30 McGee TL, Yandell DW, Dryja TP. Structure and partial genomic sequence of the human retinoblastoma susceptibilily gene. Gene 1989;80:119-28. 